\title{
Genetic Divergence Analysis in Ivy Gourd (Coccinia grandis)
}

\author{
Jitendra Kumar Tak ${ }^{1}$, Shalini Pilania ${ }^{1}$, Abhay Dashora ${ }^{2}$, \\ S.S. Lakhawat ${ }^{1}$ and Suchitra Dadheech ${ }^{3}$
}

${ }^{1}$ Department of Horticulture, RCA, Udaipur, ${ }^{2}$ Genetics \& Plant Breeding, RCA, Udaipur;

${ }^{3}$ Horticulture, COA, Bhilwara, India

Maharana Pratap University of Agriculture \& Technology, Udaipur, Rajasthan, India

*Corresponding author

\section{A B S T R A C T}

Keywords

Cluster, Diversity, hybridization, Ivy gourd

Article Info

Accepted:

12 December 2020

Available Online:

10 January 2021
Mahalanobis $\mathrm{D}^{2}$ statistics were used to study genetic divergence for 30 genotypes of ivy gourd. On the basis of divergence analysis these genotypes were grouped into 05 clusters. Clusters I was the largest one with 22 genotypes. The inter-cluster distances were greater than intra-cluster distance revealing considerable amount of genetic diversity among the genotypes studied. The maximum inter-cluster distance was observed between clusters II and V, Selection of superior genotypes from these clusters may be used in hybridization programme. The characters viz., ascorbic acid content, inter nodal length, leaf length and leaf width appeared promising which could be gainfully utilized.

\section{Introduction}

Vegetables constitute an important component of balance diet for human being. These are natural protective food and rich in vitamins and minerals. During 2019, the total production of vegetables was estimated to be at approximately 185 million metric tonnes. India has varied agro-climate zones making the country more suitable for production of various vegetable crops. There is a great scope of increasing the production and consumption of vegetable, to ensure balanced diet for the masses.

Ivy gourd (Coccinia grandis L.) also known as "kundru or tindori" is a highly nutritious valuable wild edible underutilized vegetable with domestication potential. It is important due to its nutritive value and contains water $94 \%$, dietary fibre $1.6 \mathrm{~g}$, protein $1-2 \mathrm{~g}$, fat 0.4 $\mathrm{g}$, carbohydrates $3.1 \mathrm{~g}$, carotene $156 \mu \mathrm{g}$, iron $14 \mathrm{mg}$, vitamin-A $260 \mathrm{IU}$, vitamin-C $28 \mathrm{mg}$, energy $18 \mathrm{kcal}$. A daily consumption of $100 \mathrm{~g}$ 
fruits is effective for lowering sugar content of diabetic patients. It is rich in vitamin $C, B_{1}$ and $\mathrm{B}_{2}$ which is straightening the bones. These vitamins are required to strong the immune system of human body. Tendrils of ivy gourd are also rich in mineral like potassium, calcium and iron, which are needed in optimum quantity for functioning of body.

Various parts of Coccinia grandis have specific medicinal value as reported by many researchers. Leaf extract active against Shigella flexneri, Bacillus subtilis, Escherichia coli, Salmonella choleraesuis (Bhattacharya, 2010).

Commercial cultivation of ivy gourd not picking up mainly due to lack of awareness among the people about this potential tropical vegetable. Underutilized vegetables have immense potential for contribution to a particular area of food production because they are well adapted to existing as well as adverse environmental conditions and are generally resistant to pest and pathogens. In Rajasthan, it is not cultivated but available as a wild plant in between the rocks and on field boundaries and cactus plant. This state possesses diverse germplasm of ivy gourd which will provide immense scope to popularize the underutilized vegetable through breeding programme.

To breed an adaptable cultivar for wide agroclimatic zones, selection of suitable parents is important. The divergence parents are expected to yield high heterosis and provide better new varieties. To assess the divergence in lines, Mahalanobis $D^{2}$ Statistics (1936) has been used as an effective tool in quantifying the degree of genetic divergence in different crops. Keeping these facts in view, an effort has been made to assess genetic diversity among 30 genotypes of Ivy gourd and also the contribution of each trait to the total diversity.

\section{Materials and Methods}

For present investigation, the material comprised of 30 samples collected from nearby forest locations of Udaipur, Rajasthan. Plants were identified from area having high density of ivy gourd plants. Density was selectively higher in fencing. For in-situ study, fruits, leaf were collected from each selected plant for data recording during 2018.In in-situ study, it was very complicated to select the plant of similar age and environment, therefore observations were recorded for such characters that were relatively less affected by these factors are easily assessable at the time of data recording. Observations were recorded on randomly selected plants of each genotype for 12 characters viz., inter nodal length $(\mathrm{mm})$, petiole length $(\mathrm{mm})$, leaf length $(\mathrm{cm})$, leaf width $(\mathrm{cm})$, fruit length $(\mathrm{cm})$, fruit diameter $(\mathrm{cm})$, fruit weight $(\mathrm{g})$, fruit volume $(\mathrm{cc})$, moisture content (\%), ascorbic acid content $(\mathrm{mg} / \mathrm{g})$, total chlorophyll content in leaves $(\mathrm{mg} / \mathrm{g})$ and protein content $(\mathrm{mg} / 100 \mathrm{~g}$ edible portion). For each collection fruits were harvested at horticultural maturity stage. Mean values of 12 characters studied were subjected to statistical analysis adopting standard statistical procedure.Genetic divergence was calculated by using Mahalanobis's $\mathrm{D}^{2}$ (1936) statistics as suggested by Rao (1952). The protein contents (mg/100 g edible portion) were estimated by Lowry's method (Lowrey et al., 1951). Genotypes were grouped into various clusters by Tocher's method as described by Rao (1952).

\section{Results and Discussion}

The analysis of variance revealed significant differences among the genotypes for all the traits under study. A set of 30 genotypes of ivy gourds were subjected to $\mathrm{D}^{2}$ analysis for 12 characters and based on $\mathrm{D}^{2}$ values five 
clusters were formed (Table 1). This indicated that substantial diversity existed in all the genotypes evaluated in the present study. The present study also suggests that, there is no relationship between geographical and genetic diversity as genotype chosen from different eco geographical regions are grouped in different clusters. The 30 ivy gourd genotypes grouped into 05 clusters on the basis of their relative magnitude of $\mathrm{D}^{2}$ values. Clusters I was the largest one with 22 genotypes followed by cluster II, III with 3 genotypes and cluster IV and V with a single genotype. Similar grouping was also done by Wondimu et al., (2014).
Magnitude of inter-cluster distance measures the genetic distance between two clusters while intra-cluster distance measures the extant of genetic diversity between the genotypes of same cluster. The mean intracluster distance ranged from 0.00 (cluster IV to cluster V) to 147.51 (cluster III). The cluster III had maximum intra-cluster distance (147.51) followed by cluster I (118.52), and cluster II (90.17). The highest intra-cluster distance among the genotypes of these clusters was mainly due to wide genetic diversity in the genotypes.

Table.1 Distribution of Ivy gourd genotypes into different clusters

\begin{tabular}{|c|c|l|}
\hline Clusters & $\begin{array}{c}\text { Number of } \\
\text { genotypes }\end{array}$ & Genotypes Names \\
\hline I & 22 & $\begin{array}{l}\text { UT-1, UT-2, UT-3, UT-5, UT-6, UT-7, UT-8, UT-9, UT-11, } \\
\text { UT-12, UT-18, UT-19, UT-20, UT-21, UT-22 UT-23, UT- } \\
24, \text { UT-25, UT-26, UT-27, UT-28, UT-29 }\end{array}$ \\
\hline II & 3 & UT-10, UT-14, UT-15 \\
\hline III & 3 & UT-13, UT-17, UT-30 \\
\hline IV & 1 & UT-16 \\
\hline V & 1 & UT-4 \\
\hline
\end{tabular}

Table.2 Average intra (bold) and inter cluster distance based on corresponding $\mathrm{D}^{2}$ Values in Ivy gourd

\begin{tabular}{|c|c|c|c|c|c|}
\hline Cluster & I & II & III & IV & V \\
\hline I & $\mathbf{1 1 8 . 5 2}$ & 245.61 & 195.75 & 199.71 & 392.34 \\
\hline II & & $\mathbf{9 0 . 1 7}$ & 491.54 & 452.05 & 844.65 \\
\hline III & & & $\mathbf{1 4 7 . 5 1}$ & 236.50 & 262.94 \\
\hline IV & & & & $\mathbf{0 . 0 0}$ & 212.83 \\
\hline $\mathbf{V}$ & & & & & $\mathbf{0 . 0 0}$ \\
\hline
\end{tabular}


Table.3 Mean values of different characters for 30 Ivy gourd genotypes grouped into five clusters

\begin{tabular}{|c|c|c|c|c|c|c|c|c|c|c|c|c|}
\hline Cluster & $\begin{array}{c}\text { Inter } \\
\text { nodal } \\
\text { length } \\
(\mathbf{m m})\end{array}$ & $\begin{array}{l}\text { Petiole } \\
\text { length } \\
\text { (mm) }\end{array}$ & $\begin{array}{c}\text { Leaf } \\
\text { length } \\
(\mathrm{cm})\end{array}$ & $\begin{array}{c}\text { Leaf } \\
\text { width } \\
(\mathrm{cm})\end{array}$ & $\begin{array}{l}\text { Fruit } \\
\text { length } \\
(\mathrm{cm})\end{array}$ & $\begin{array}{c}\text { Fruit } \\
\text { diameter } \\
(\mathrm{cm})\end{array}$ & $\begin{array}{c}\text { Fruit } \\
\text { weight } \\
\text { (g) }\end{array}$ & $\begin{array}{c}\text { Fruit } \\
\text { volume } \\
\text { (cc) }\end{array}$ & $\begin{array}{c}\text { Moisture } \\
\text { content } \\
(\%)\end{array}$ & $\begin{array}{l}\text { Ascorbic } \\
\text { acid } \\
\text { content } \\
(\mathrm{mg} / \mathrm{g})\end{array}$ & $\begin{array}{c}\text { Total } \\
\text { chlorophyll } \\
\text { content in } \\
\text { leaves } \\
(\mathrm{mg} / \mathrm{g})\end{array}$ & $\begin{array}{l}\text { Protein } \\
\text { content } \\
\text { (mg/100 } \\
\text { g edible } \\
\text { portion) }\end{array}$ \\
\hline I & 90.65 & 3 & 8. & 7.74 & & & 20. & & & & 0.87 & 1150.86 \\
\hline II & 56.00 & 34.44 & 5.42 & 7.11 & 5.43 & 2.10 & 19.72 & 1.07 & 93.57 & 1.44 & 0.95 & 6.56 \\
\hline III & 110.78 & 40.44 & 8.31 & 8.29 & 6.64 & 2.34 & 15.60 & 1.08 & 93.33 & 1.26 & 0.92 & 1179.11 \\
\hline IV & 100.33 & 35.00 & 12.20 & 11.30 & 7.37 & 2.67 & 20.60 & 1.06 & 93.43 & 1.39 & 0.76 & 1196.67 \\
\hline V & 147.33 & 70.33 & 12.27 & 10.27 & 4.53 & 2.00 & 17.10 & 1.07 & 93.77 & 1.34 & 0.77 & 1116.00 \\
\hline
\end{tabular}


Table.4 Per cent contribution of different characters in Ivy gourd

\begin{tabular}{|c|c|}
\hline Character & Per cent contribution \\
\hline Inter nodal length (mm) & 18.63 \\
\hline Petiole length (mm) & 5.40 \\
\hline Leaf length $(\mathrm{cm})$ & 14.72 \\
\hline Leaf width $(\mathrm{cm})$ & 10.95 \\
\hline Fruit length $(\mathrm{cm})$ & 6.28 \\
\hline Fruit diameter $(\mathbf{c m})$ & 1.92 \\
\hline Fruit weight (g) & 6.02 \\
\hline Fruit volume (cc) & 1.42 \\
\hline Moisture content (\%) & 1.46 \\
\hline Ascorbic acid content $(\mathrm{mg} / \mathrm{g})$ & 20.55 \\
\hline $\begin{array}{l}\text { Total chlorophyll content in leaves } \\
(\mathrm{mg} / \mathrm{g})\end{array}$ & 6.51 \\
\hline $\begin{array}{l}\text { Protein content }(\mathrm{mg} / 100 \\
\text { portion) }\end{array}$ & 6.13 \\
\hline
\end{tabular}

The inter-cluster distance are the main criteria for selection of genotypes using $\mathrm{D}^{2}$ analysis. As evident from Table 2, the average intercluster distances were greater than intracluster distance revealing considerable amount of genetic diversity among the genotypes studied.

The maximum inter-cluster distance (D) was observed between clusters II and V (844.65) followed by cluster II and III (491.548), cluster II and IV (452.05) and cluster I and V. It showed that the genotypes concerned with these clusters have wide genetic diversity. As the magnitude of heterosis depends largely on the degree of genetic diversity in the parental line, genotypes belonging to diverse clusters could be used in hybridization programme. The minimum inter-cluster distance was found between clusters I and II (195.75).

The mean values of different clusters are presented in Table 3.Cluster II had genotypes having higher mean values for ascorbic acid content and total chlorophyll content in leaves, Cluster IV had high value for leaf width, fruit length, fruit diameter, fruit weight, protein content and Cluster $\mathrm{V}$ had Inter nodal length $(\mathrm{mm})$, Petiole length $(\mathrm{mm})$, Leaf length $(\mathrm{cm})$ and Moisture content $(\%)$. Therefore, hybridization between the selected genotypes from divergent clusters is essential to judiciously combine all the targeted traits. The result found in present investigation was in agreement with the results of Resmi and Sreelathakumary (2012). The characters contributing maximum to the divergence were gives greater emphasis for deciding the cluster type for the purpose of further selection and the choice of parents for hybridization programme. The results revealed that the traits viz., ascorbic acid content (20.55), inter nodal length (18.63), leaf length (14.72) and leaf width (10.95) contributed more towards the total genetic divergence among 30 ivy gourd genotypes, so that the direct selection for these traits would helpful as evident from number of times these traits appeared or ranked first during contribution to diversity (Table 4).

On the basis of divergence studies in ivy gourd and its clustering pattern for different characters, it could be concluded that genetic 
diversity did not show any relationship with geographical diversity.

Characters like ascorbic acid content, inter nodal length, leaf length and leaf width appeared promising which could be gainfully utilized. Twenty genotypes of ivy gourd were grouped into 5 clusters and clusters II and V had maximum inter-cluster distance, therefore, the genotypes belonging to these clusters could be effectively utilized by either selecting superior types or following recombination breeding.

\section{References}

Bhattacharya et al.(2010).Evaluation of Antifungal and Antibacterial Activities of the Plant Coccinia grandis (L.) Voigt. (Family- Cucurbitaceae). J Phytol 2/11 (2010) 52-57

Lowry, O.H., Rosebraugh, N.J., Farr, A.L. and Randall, R.J. 1951. Protein measurement with the folin phenol reagent. The Journal of Biological Chemistry, 193 (1): 265-275.

Mahalanobis, P.C. 1936. On the general distance in statistics. Proc. of Nation. Academy of Science (India), 12: 49-55.

Rao, C. H. 1952. Advanced Statistical Methods in Biometric Research. John Wiley \& Sons, New York.

Resmi, J. and Sreelathakumary, I. 2012. Studies on genetic divergence in bitter gourd (Momordica charantia L.), Journal of Horticultural Sciences, 7(2): 152-155.

Wondimu T., Alamerew S., Alana, A and Garedew, W. 2014. Genetic diversity analysis among anchote (Coccinia abyssinica) accessions in western Ethiopia. International Journal of Agricultural Research, 9(3): 149-157.

\section{How to cite this article:}

Jitendra Kumar Tak, Shalini Pilania, Abhay Dashora, S.S. Lakhawat and Suchitra Dadheech. 2021. Genetic Divergence Analysis in Ivy Gourd (Coccinia grandis). Int.J.Curr.Microbiol.App.Sci. 10(01): 1336-1341. doi: https://doi.org/10.20546/ijcmas.2021.1001.159 